\title{
Under the Radar: State Associations and Election Administration
}

\author{
David C. Kimball \\ University of Missouri-St. Louis \\ dkimball@umsl.edu \\ Brady Baybeck \\ Wayne State University \\ brady.baybeck@wayne.edu \\ Ray Deppen \\ University of Missouri-St. Louis
}

\begin{abstract}
This paper is part of a larger project on the urban and rural dimensions of election administration. There is a dramatic skew in the distribution of voters across local jurisdictions. We enumerate the state associations of local election officials and examine how they aggregate their members' preferences on election laws and procedures, with a focus on early voting policies. We hope that our findings will bring a much needed local focus to the nationalized discussion over election reform and highlight the nexus between politics and administration in a very important policy arena.
\end{abstract}

Prepared for presentation at the annual meeting of the Midwest Political Science Association, Chicago, April 4, 2014. 
The passage of the Help America Vote Act of 2002 (HAVA) significantly increased the scrutiny of election administration in the United States. Scholars, policymakers, and practitioners have spent the past decade assessing election laws and administration, seeking improvements. Today we have a better understanding of elections, and certainly there is no shortage of proposals to reform election laws in the United States. Many of these proposals have become ideologically charged and policy debates over them have achieved national prominence.

However, most of these reforms will be adopted and implemented by a highly fragmented and decentralized system of state governments and local election administrators. Almost all of the new election laws passed since in the last decade have been adopted at the state level. Furthermore, there is tremendous variation in the size of local jurisdictions, which makes for very different experiences for voters and election officials in large versus small jurisdictions. Very little is known about this process of state and local implementation of election laws, in particular the relationship between state policy makers and local election officials. In this paper, we begin to examine how local election administrators have their policy views heard as state legislatures consider reform. We will focus on the influence that state associations of election administrators have upon the policy debates. We hypothesize that these associations play a role in these debates, but that the voices that get heard depend upon the internal political dynamics of the organizations and the geographic distribution of voters within each state.

Because of how local government boundaries have been drawn, and longtime migration patterns, jurisdictions vary dramatically in terms of the size of the voting population they serve. The geographic distribution of voters means that there are many more small jurisdictions than there are large-less than 6 percent of the local election officials in the United States serve more than two-thirds of the voters in national elections. The interaction of local autonomy and size 
disparities leads to real differences in how elections are administered. Local officials in heavily populated jurisdictions bear a disproportionate share of the challenges of election administration. This means that larger jurisdictions tend to be more interested in policy and administrative innovation.

However, the skewed distribution of voters across local jurisdictions challenges election law and administration in two important ways. First, it challenges the presumption that uniform voting laws and procedures promote fairness. For example, a law that satisfies the needs of large jurisdictions may not be preferred by small jurisdictions. Second, it tends to place heavily populated urban jurisdictions at a numerical disadvantage in state deliberations about election reforms. The recommendations of local officials serving large jurisdictions may be drowned out by the more numerous officials in other jurisdictions who serve vastly smaller voting populations. As a result, the skewed geographic distribution of voters hinders innovation in election laws and administration in the places that need it most.

\section{Innovation in Elections Takes Place Primarily at the State and Local Levels}

Most of the innovation in election laws and administration takes place at the state and local level. With the exception of the reauthorization of the Voting Rights Act in 2006, no federal election laws have been passed since HAVA was adopted in 2002. Given the highly partisan nature of many election law debates, it is unlikely that Congress will pass election legislation in the near future. It is instructive that practically all of the recommendations in the recent report from the Presidential Commission on Election Administration (2014) are directed at state and local governments. The report offers no major legislative proposals for Congress. 
In contrast, state and local governments have been making a host of recent election reforms. Over the past decade, hundreds of new state election laws have been enacted (National Conference of State Legislatures 2014). Furthermore, since 2006 more than half of the states have passed new voting restrictions, such as requirements that voters show photo identification or proof of citizenship, limits on voter registration, or restrictions on early and absentee voting (Bentele \& O’Brien 2013). At the same time, several states have recently adopted reforms, such as online or Election Day voter registration, designed to reduce barriers to voting.

Local jurisdictions are another important source of innovation in election administration and have been so for a long time (Ewald 2009). Local jurisdictions have a lot of discretion in enforcing state and national election laws. Thus, local jurisdictions have initiated many improvements in ballot design, in recruiting, managing, training, and evaluating poll workers, and in contacting and educating voters. At least recently, heavily populated jurisdictions have led the way in these innovations (Kimball and Baybeck 2013). Many municipalities are also in a position to adopt more extensive reforms for local elections. Recent examples of reforms first adopted at the local level include early voting centers (Stein and Vonnahme 2008), ranked choice voting (Neely and Cook 2008), and pre-registration of 16 and 17 year olds. The federal structure of American government encourages state and local innovation. In elections, however, it also gives rise to a dramatic skew in the distribution of voters.

\section{The Geographic Distribution of Voters across Local Jurisdictions}

Previously, we have described the tremendous variation in jurisdiction size and the challenges that poses for election administration in the United States (Kimball and Baybeck 
2013). In addition to serving most of the nation’s voters, heavily populated local jurisdictions also contain a younger, more diverse, and more mobile population. Large jurisdictions serve substantially more voters per polling place than small jurisdictions. Finally, large metropolitan jurisdictions contain many more sub-governments than smaller jurisdictions. All of these features of local government complicate the task of planning and holding elections in large jurisdictions. The administrative challenges of holding elections in the largest local jurisdictions are concentrated in two areas: (1) maintaining accurate information about their registered voters, and (2) managing a large and complex system of polling places and poll workers. In turn, most of the difficulties facing voters and election officials, including long lines for voters, suboptimal poll workers, registration problems, poor voting experiences, and rejected absentee and provisional ballots, occur disproportionately in a small number of heavily populated local jurisdictions. Thus, large local jurisdictions have the greatest need for reform and are a critical force for innovation in election law and administration.

To illustrate the size disparity in election administration, we identify 7,858 local jurisdictions that have the primary responsibility for administering state and federal elections within their specific geographic boundaries. We divide the universe of local jurisdictions into four size categories: small (serving less than 1,000 voters), medium (serving between 1,000 and 50,000 voters), large (serving between 50,000 and 500,000 voters), and extra-large jurisdictions (more than 500,000 voters). Jurisdictions with fewer than 1,000 voters are generally small towns that typically have just one polling place and a handful of poll workers. We expect these jurisdictions to have a different election administration experience than larger jurisdictions. In addition, roughly one-third of the jurisdictions in the country served less than 1,000 voters in recent presidential elections, so this serves as a natural break in the data. 
We chose 50,000 voters as another dividing line because jurisdictions serving more than 50,000 voters tend to be in densely populated metropolitan areas with a large central city. Thus, larger jurisdictions have different infrastructure and transportation networks than the mediumsized jurisdictions, which are mostly rural and exurban counties. Finally, the extra-large category contains the 31 most populous local jurisdictions in the country. These jurisdictions are part of the largest metropolitan areas in the county and face disproportionate concentrations of many of the voting problems described above (Kimball 2013). The smallest jurisdictions are primarily municipalities in the upper Midwest and New England, but also include several rural counties in the Plains states.

Figure 1 illustrates the dramatically skewed distribution of voters across local jurisdictions with data from the 2012 presidential election. Almost 95 percent of the local jurisdictions administering elections are in the small (36\%) or medium (58\%) categories. Very few local jurisdictions serve large voting populations. Roughly 6 percent of the local jurisdictions served a bit more than two-thirds of the voters in the 2012 election. Meanwhile, the thirty most populated jurisdictions serve more than 20 percent of the nation's voters. When casting their ballots, the vast majority of American voters are served by a very small number of heavily populated local jurisdictions.

[Figure 1 about here]

Furthermore, as the American population continues to move from rural areas to urban and suburban regions, the skew in the size of local jurisdictions is growing. Figure 2 shows the change in voter turnout between the 2004 and 2012 elections for each category of jurisdiction size. Voter turnout increased by roughly 6.6 million voters between the 2004 and 2012 
presidential elections. Almost 90 percent of the turnout growth occurred in the large and extralarge jurisdictions: about 4.5 million of those additional voters came in large jurisdictions, with another 1.4 million in the extra-large jurisdictions. Turnout did not increase (in fact, it decreased slightly) in small jurisdictions. A small number of local jurisdictions bear most of the responsibility for registering voters and counting ballots, and their share of the burden is increasing. In response to these challenges, election officials in large jurisdictions engage in a host of innovative practices to register voters and manage an extensive set of polling place operations (Kimball et al. 2010). Many of those new practices are unnecessary in smaller jurisdictions.

[Figure 2 about here]

\section{The Geographic Distribution of Election Administration Preferences}

There is renewed interest in American political science in the geographic distribution of political preferences, perhaps due in part to the scrutiny given to the impact of redistricting on political representation. As one of the classic works in political geography observes, "Voters cannot be regarded as scattered at random over the various constituencies" (Kendall and Stuart 1950, 188). Several applications of this insight note that liberal voters and the poor are concentrated in densely populated urban districts in many countries. Even with neutral redistricting plans, this geographic distribution can produce electoral biases that punish leftist parties, particularly in countries with plurality election systems. In terms of Downsian spatial theory, the reason for the bias is that the geographic distribution of voters produces a left skewed distribution of policy preferences across districts. As a result, the preference of the median voter in the median district tends to be more conservative than the median voter in the nation (Rodden 
2010; Chen and Rodden 2013). This electoral bias then produces policy biases that favor wealthy interests (Bradbury and Crain 2005; Rodden 2010). Others pin the policy bias against urban interests in state legislatures on the size of urban delegations and the concentration of immigrants in cities (Gamm and Kousser 2013). In any case, the geographic distribution of voters in a democracy can have a profound influence on political parties, elections, and public policy.

Research on the skewed distribution of voters across local jurisdictions has focused primarily on legislative districts as the geographic units producing political bias. Even in the presence of the "one person, one vote" criterion it is quite evident that policy bias emerges. Urban interests - and Democrats - are at a disadvantage due to the geographic distribution of their populations (Chen and Rodden 2013). It is our contention, however, that the policy process for election administration is further warped by this geographic bias in distribution of voters across local election jurisdictions. Whereas legislative districts are drawn to capture roughly equal populations, there are no such restrictions or guidelines on the units that conduct elections. In fact, it is fair to say that the geographic boundaries of election jurisdictions - cities, counties, towns, and townships - have remained remarkably stable through time. Their boundaries also emerged through historical processes quite independent of any demographic shifts or current policy design.

The State of Missouri provides a fairly representative example of this issue. Local election administration in Missouri is handled by 116 jurisdictions - the 115 counties plus an independent city board of election in Kansas City. With the exception of Kansas City (and St Louis City in 1875), these boundaries have changed very little, if at all, since Missouri’s entrance into the U.S. as a state in 1821. The vast majority of Missouri counties started out as rural and quite small in population, and have remained that way. 
If these units of government were purely administrative in function, this distribution would have very little policy consequence. But as noted previously the administration of elections is not purely administrative - local election officials have significant discretion and are in many cases independently selected to their positions. More important for the purposes of this paper, within the state legislative process local election administrators play very important roles as advocates and policy entrepreneurs, as they obviously know more about the elections process through their front line experience. Thus when it comes to the production of election laws and regulations, it is also worth considering the distribution of local election jurisdictions in each state. If local election officials, by themselves or through state associations, advocate for the needs and preferences of their constituents then the geographic distribution of voters across local jurisdictions is very important.

Figure 3 attempts to do this by plotting a histogram of all 7,858 local jurisdictions arrayed by size in the 2012 election. The height of each bar indicates the share of the electorate in each bin. Since there is such a dramatic right skew in the size of local jurisdictions, the horizontal axis is displayed on a logarithmic scale to more easily fit the data on one page. As indicated by the dashed line in the graph, the median jurisdiction had roughly 2,100 voters in the 2012 election. In contrast, the median voter in the nation resides in a much larger jurisdiction, one with approximately 144,000 voters. While the median voter lives in a jurisdiction where most of the election administration problems occur, the median jurisdiction experiences almost none of those problems. While the graph shows all local jurisdictions in the nation, the same skew in the distribution of voters is present in almost all states (Kimball and Baybeck 2013, Table 5). In most states, election officials serving heavily populated jurisdictions find themselves at a numerical disadvantage when competing with other local officials to influence policymakers. 
[Figure 3 about here]

The question then is whether the election policy preferences of citizens and local officials vary by jurisdiction size and how those preferences are communicated to lawmakers. The voting preferences of American voters are increasingly diverging by urban versus rural place of residence (Gimpel and Karnes 2006). Legal and political conflicts between densely populated urban areas and less populated rural areas have been common in the United States (Key 1964; Ansolabehere and Snyder 2008; Walsh 2012). Scholars tend to situate these conflicts around differences over cultural values, individualism, and the distribution of government benefits. If anything these political differences have grown larger in recent years.

Figure 4 is a boxplot showing President Obama's share of the major party presidential vote by jurisdiction size in the 2012 election. The top and bottom of each box indicates the $75^{\text {th }}$ and $25^{\text {th }}$ percentile observations respectively, while the horizontal line inside the box denotes the median case. The figure shows that jurisdiction size is associated with partisan voting preferences in the United States. In the extra-large jurisdictions, Obama received 63\% of the vote in 2012, a higher share for a Democratic presidential candidate in urban American than in other recent elections (Gimpel and Karnes 2006). In the large jurisdictions, Obama received 53\% of the vote while he received $43 \%$ in the medium-sized jurisdictions. Since most of the small jurisdictions are in New England and the Upper Midwest, traditional regions of strength for Democrats, support for Obama ticked up a bit in the small jurisdictions. While Obama won the national popular vote by five million votes, in the median local jurisdiction Romney outpolled Obama $55 \%$ to $45 \%$, further evidence that the geographic distribution of voter preferences is clearly skewed. 
[Figure 4 about here]

Just because the voting preferences of urban and rural Americans are substantially different does not necessarily mean that their preferences on election laws and procedures differ. In this paper we focus on policies related to early voting. There is evidence that individualism is a more deeply held core value among rural Americans than among urban residents (Gimpel and Karnes 2006), which also leads us to expect a stronger preference for convenience-based reforms like early voting in heavily populated urban jurisdictions. Unfortunately, we have not found public opinion data on early voting preferences where respondents can be connected to their local jurisdiction. The closest we get are questions on the Survey for the Performance of American Elections that ask about moving Election Day to a holiday or to the weekend (Stewart 2008). These policies are somewhat similar to early voting in allowing voting at times that may be more convenient for many voters. Table 1 shows support for both policies among respondents in local jurisdictions of different sizes. As expected, the results show modestly stronger preferences for holiday and weekend voting among residents of the most heavily populated jurisdictions.

[Table 1 about here]

There is clearer evidence that election policy preferences differ among local election officials serving large versus small jurisdictions. For example, local officials in large jurisdictions are more supportive of additional staff and resources to help them cope with the challenging environment in which they serve (Kimball et al. 2010). More importantly, there is substantial evidence that local election officials in large jurisdictions mostly support expanded early voting while officials in smaller jurisdictions generally oppose early voting (Kimball and 
Baybeck 2013; Burden et al. 2011; Kimball et al. 2010). More generally, officials in large jurisdictions tend to favor expanded voting hours and methods that may help minimize the crush of voters who will otherwise clog polling place on Election Day. In contrast, officials in smaller jurisdictions tend to oppose election reforms, such as HAVA and early voting, that will cost more to implement and provide relatively minimal benefits to their constituents (Kropf and Kimball 2012).

\section{Jurisdiction Size and Election Reform: The Case of Early Voting}

Because of the skewed distribution of the voters across local jurisdictions, we suspect that election reform debates in many states are dominated by election officials from small and medium-sized jurisdictions, even though they serve a relatively small share of voters. In particular, state associations of local election officials are likely influential advocates in state legislative debates about election laws. In the vast majority of states, the composition of state associations reflects the distribution of local jurisdictions in Figures 1 and 3 . Assuming that state associations aggregate preferences with democratic institutions (e.g., one person, one vote, with majority rule) then the heavily populated jurisdictions are a relatively small voice when policy preferences are conveyed to lawmakers. Given different preferences for early voting in large versus small jurisdictions, we expect that state policy will be shaped by the geographic distribution of voters across local jurisdictions within states. We test this hypothesis with case studies of several states that have debated early voting adoption or restrictions on its use.

Early voting has become a more contentious election policy as its use has expanded rather rapidly. A recent flashpoint is efforts in several states to restrict the early voting period 
and eliminate early voting on weekends or Sundays. This comes in the wake of organized "souls to the polls” efforts in some swing states to transport African Americans to early voting locations after Sunday church services in the last two presidential elections (Herron and Smith 2012). One recent puzzle is that some states with GOP majorities in the legislature have limited early voting while another, Florida, recently restored previous restrictions on early voting. We believe that the distribution of voters across local jurisdictions, and the resulting configuration of interests in state associations of local election officials, helps explain this puzzle.

Our working hypothesis is that partisanship and jurisdiction size interact to predict the likelihood of support among election administrators. Table 2 presents our typology of interaction. Jurisdictions that are small and have Republican administrators are the most likely to be opposed to innovation for reasons both partisan and administrative. Jurisdictions that are large with Democratic administration would obviously support innovations. It is the remaining two that are most interesting to us, as they are jurisdictions that fall outside of the predictive power of partisanship. It is also where we might find more nuances in the level of support for innovation. A Republican administrator in a large jurisdiction might be willing to support expanded early voting policies, against her party’s preferences, that would make the voting process more efficient and perhaps easier for citizens. Similarly, a Democratic administrator in a small jurisdiction - of which there are admittedly fewer of these - would be reluctant to support innovation.

[Table 2 about here]

Why does this matter? Because the preferences of election administrators are aggregated into the statewide associations of election administrators, where, in most states, the smaller 
jurisdictions hold a substantial numeric advantage. Rather than "one person, one vote," it is "one jurisdiction, one vote” when local officials communicate their preferences to the state legislature, and this has consequences. In almost every state, an association is a key institution offering advice to the state legislature on election reform proposals. Local election officials and their association routinely testify in state legislatures about election reform bills. Local election officials are frequent sources in news coverage of election laws and procedures. The vast majority of local election officials are chosen by local voters or local government (Kropf and Kimball 2012), so they tend to be treated as trustworthy advocates for the needs and preferences of their local voters. In most states, the association of local officials is one of the few organizations with the credibility to break through the din of partisan conflict over election laws. Just about every state has an association of local election officials ${ }^{1}$ that engages in three main activities: (1) training local officials and their staff; (2) providing information about administrative best practices; and (3) legislative advocacy. We focus on advocacy, and the manner in which local preferences are transmitted to the legislature via the state association.

Officials in the largest Missouri jurisdictions have been pressing for legislation to allow early voting for several years. In addition, Jason Kander, the Democratic Secretary of State elected in 2012, has launched a public campaign in support of expanded early and absentee voting. Upon taking office, Kander formed a committee of local officials and other constituencies to study early voting, which then produced a report recommending its adoption in Missouri (Kander 2013). Out of 116 local jurisdictions that administer elections in Missouri only 10 are large or extra-large by our classification, but they serve more than half of the state's

\footnotetext{
${ }^{1}$ One exception is Alaska, where the state government manages elections and hires local administrators. There is also a regional association of city and town clerks for the New England states, although there is a separate association of clerks in each state.
} 
voters. Early voting proposals have gained little traction in Missouri, in part because election officials in smaller counties have long opposed it. Associations of county clerks in the state have repeatedly testified against early voting legislation mainly due to the cost of implementation (Ganey 2011; Associated Press 2001). The smaller counties exert disproportionate influence in the state association and the state capitol. Furthermore, the current chair and the most active member of the Missouri House elections committee are former county clerks from counties with fewer than 14,000 voters apiece in 2012. One of them is on record opposing early voting in Missouri (Livengood 2008). These factors make the prospects for early voting in Missouri dim.

Wisconsin has also debated early voting recently. Since Republicans won control of state government in Wisconsin in 2010, they have twice passed laws restricting early voting. In 2011, Wisconsin reduced the early voting period from three weeks and three weekends to two weeks and one weekend. In 2014, Wisconsin further reduced early voting to weekdays only. Conflicting interests of urban and rural communities was a key source of partisan disagreement over both laws. Democrats argued that weekend early voting was convenient for many urban residents and the limits on early voting were designed to make it harder for their residents to vote. Republicans countered that rural communities could not afford to keep early voting offices open on the weekends. Regarding weekend early voting, state senator Glenn Grothman ( $\mathrm{R}$ - West Bend), the sponsor of the 2014 law, stated "There's no demand (for that) in any community in my district" (Stein and Walker 2014). The largest municipality in Grothman's $20^{\text {th }}$ Senate district (West Bend) had fewer than 17,000 voters in the 2012 election. While the municipal and county clerks associations in Wisconsin successfully opposed Republican attempts to eliminate Election Day registration, and testified against photo ID legislation in Wisconsin, it appears that the clerks associations did not mount an organized effort to stop the early voting restrictions. Out of 1,895 
municipalities in Wisconsin, just two (Milwaukee and Madison) are large according to our size categories; more than 1,400 are small. Evidence from Wisconsin indicates that clerks in the smaller jurisdictions are more opposed to early voting than clerks serving large jurisdictions (Burden et al. 2011). It is quite possible that most municipal clerks in Wisconsin would side with the Republican position on early voting, which may be why the clerks associations stayed on the sideline in the early voting debate.

Ohio is another swing state that recently limited early voting. The legislature and governor recently passed a law that reduced the early voting period by six days and ended sameday registration. Republican Secretary of State Jon Husted followed a few days later by announcing new regulations prohibiting early voting on Sundays for this year's gubernatorial election. Husted's regulation was based on a bipartisan recommendation on uniform early voting times made by the Ohio Association of Election Officials (OAEA 2013a). However, the geographic distribution of voters across Ohio's 88 counties is almost as skewed as the national distribution in Figure 3. Less than one-third of Ohio counties fall in the large or extra-large categories. The OAEA rules give equal voting power to each county (OAEA 2013b), so any plan adopted by the organization is heavily influenced by the more numerous small counties in the state. As a result, elected officials from the state's most populous counties are clearly not happy with the state’s new early voting schedule (Pelzer 2014).

In contrast, even though it too has a Republican governor and large GOP majorities in the legislature, Florida is moving in the opposite direction on early voting. In 2011, Florida passed HB 1355, a controversial law that, among other things, reduced early voting from 14 days to 8 days and eliminated early voting on the Sunday before Election Day. A recent study found that young voters, racial and ethnic minorities, Democrats, and first-time voters were most likely to 
be inconvenienced by the law, particularly the early voting provisions (Herron and Smith 2012). However, the state reversed course in 2013, passing a new law restoring 14 days of early voting and allowing county officials flexibility to open more early voting locations and offer early voting hours on the Sunday before the election. Some may ascribe the turnabout to the embarrassment of long voting lines in some Florida communities during the 2012 election. However, Florida had among the longest average wait times for voters in elections prior to 2012 (Stewart 2012). An underappreciated factor may be the county election supervisors and their state association.

Florida is a densely populated state and more than half of its 67 counties are in our large or extra-large categories. Thus, most election supervisors in the state know the challenges of serving a lot of voters and probably prefer expanded early voting. Indeed, the Florida State Association of Supervisors of Elections has been a strong supporter of restoring early voting and the association helped the legislature craft the 2013 law expanding early voting. The state association has frequently pushed the state for more flexibility in implementing state laws and directives, in areas including early and absentee voting, and purging ineligible voters from the rolls (Stuart 2004; News Service of Florida 2013). Florida seems to be a case where the organization advocating for local election officials is shaped more by the needs of larger jurisdictions than in most other states.

North Carolina is the final battleground state that recently limited early voting, along with several other voting restrictions. Newly elected Governor Pat McCrory gave the GOP full control of state government, allowing them to pass the new voting law in 2013 on a party line vote. The state association of county election boards did not organize opposition to the early voting restrictions. This is not a surprise given that a majority of the county election board members are 
appointed from the governor's political party. The newly appointed GOP county boards would not be expected to oppose legislation favored by the governor. In addition, only 24 of the state's 100 counties served more than 50,000 voters in the 2012 election. The smaller counties may not have favored extensive early voting in the first place. In fact, one provision in the law allows counties to petition the state for the ability to provide fewer early voting hours than the minimum set forth in the law; 32 counties (most of them serving fewer than 20,000 voters) have used this provision to reduce early voting for the upcoming primary election in May of 2014 (Robertson 2014). Again, the distribution of voters across local jurisdictions is associated with the outcome of the statewide debate about early voting.

\section{Conclusion}

Densely populated local jurisdictions are substantially different than smaller jurisdictions in many measurable indicators of election administration. With respect to early voting, the policy preferences of voters and election officials in densely populated differ substantially from their counterparts in smaller jurisdictions. Differences between the preferences of urban and rural localities is evident in other election administration disputes, including how to contact absentee voters, methods for receiving absentee ballots, and voter list purges. While election policy disputes are frequently shaped by partisanship, the outcome of these disputes may also be influenced by the geographic distribution of voters across local jurisdictions. In most states, where small jurisdictions predominate, the election policy preferences of the jurisdictions that serve the most voters are likely diminished. The dramatic skew in the geographic distribution of voters across local jurisdictions also challenges the impulse for uniformity in election laws and 
procedures. Some policymakers and administrators insist on uniform laws and regulations as the only way to ensure fair elections. However, in some cases treating every voter fairly may be best achieved by allowing different local jurisdictions to adopt different administrative practices tailored to their local communities.

This paper, a beginning stage of a larger research project, represents a first step in understanding this important process of innovation and local election administration. In future work we plan to dig deeper into understanding the influence of the state associations in the policy process of their state. We are in the process of collecting data on the various statewide associations, and eventually will conduct interviews with key players in a limited number of states. For now, we need to be satisfied with the relatively limited insight that jurisdiction size and partisanship play an interactive role in the complex patchwork that is election administration in the United States. 


\section{References}

Ansolabehere, Stephen, and James M. Snyder Jr. 2008. The End of Inequality. New York, NY: Norton.

Associated Press. 2001. “Coalition of County Clerks Opposes Early Voting Plan.” The Southeast Missourian, February 7, 5A.

Bentele, Keith G., and Erin E. O’Brien. 2013. “Jim Crow 2.0? Why States Consider and Adopt Restrictive Voter Access Policies.” Perspectives on Politics 11:1088-1116.

Bradbury, John Charles, and W. Mark Crain. 2005. "Legislative District Configuration and Fiscal Policy in American States.” Public Choice 125:385-407.

Burden, Barry C., David T. Canon, Kenneth R. Mayer, and Donald P. Moynihan. 2011. “Early Voting and Election Day Registration in the Trenches: Local Officials’ Perceptions of Election Reform.” Election Law Journal 10:89-102.

Chapin, Doug. 2012. “Arizona Election Consolidation Bill Divides Counties.” Program for Excellence in Election Administration (http://blog.lib.umn.edu/cspg/electionacademy/2012/05/arizona_election_consolidation.php, accessed May 3, 2012).

Chen, Jowei, and Jonathan Rodden. 2013. “Unintentional Gerrymandering: Political Geography and Electoral Bias in Legislatures.” Quarterly Journal of Political Science 8:239-269.

Ewald, Alec. 2009. The Way We Vote: The Local Dimension of American Suffrage. Nashville: Vanderbilt University Press.

Fogarty, Brian J., Jessica Curtis, P. Frances Gouzien, David C. Kimball, and Eric C. Vorst. 2014. "News Coverage of Voter Fraud in the 2012 Election." Paper presented at the annual meeting of the Southern Political Science Association.

Gamm, Gerald, and Thad Kousser. 2013. "No Strength in Numbers: The Failure of Big-City Bills in American State Legislatures, 1880-2000.” American Political Science Review 107:663678.

Ganey, Terry. 2011. “Early Voting Measure Draws Opposition.” Columbia Daily Tribune, May 9 (http://lakeexpo.com/news/top_stories/article_f3471e9b-f71e-5971-8f40d91295fd7ee3.html?mode=jqm, accessed March 28, 2014).

Gimpel, James G., and Kimberly A. Karnes. 2006. “The Rural Side of the Urban-Rural Gap.” PS: Political Science and Politics 39:467-472. 
Hasen, Richard L. 2012. The Voting Wars: From Florida 2000 to the Next Election Meltdown. New Haven: Yale University Press.

Herron, Michael, and Daniel Smith. 2012. "Souls to the Polls: Early Voting in Florida in the Shadow of House Bill 1355.” Election Law Journal 11:331-347.

Kander, Jason. 2013. Secretary of State Jason Kander's Report on Early Voting: Efficiency, Fairness, and Security at the Polls, March 2013. Jefferson City, MO.

Kendall, M. G., and A. Stuart. 1950. "The Law of the Cubic Proportion in Election Results.” British Journal of Sociology 1:183-196.

Key, V. O., 1964. Politics, Parties and Pressure Groups, $5^{\text {th }}$ ed. New York: Thomas Y. Crowell Co.

Kimball, David C. 2013. "Why Are Voting Lines Longer for Urban Voters?” Paper presented at the annual meeting of the Southwestern Social Science Association, New Orleans, March 29.

Kimball, David C., and Brady Baybeck. 2013. "Are all Jurisdictions Equal? Size Disparity in Election Administration.” Election Law Journal 12(2):130-145.

Kimball, David C., Brady Baybeck, Jennifer Collins-Foley, Connie Schmidt, and Cheré Maxwell. 2010. Survey of Poll Worker Training Practices by Local Election Officials. University of Missouri-St. Louis, February 2010.

Kropf, Martha, and David C. Kimball. 2012. Helping America Vote: The Limits of Election Reform. New York, NY: Routledge.

Livengood, Chad. 2008. "Dugger not sure about Early Voting.” Springfield News-Leader, December 19 (http://www.news-leader.com/article/20081220/NEWS06/812200337/Dugger-notsure-about-early-voting, accessed March 28, 2014).

National Conference of State Legislatures. 2014. "2001-2010 Database of Election Reform Legislation.” (http://www.ncsl.org/research/elections-and-campaigns/2001-2010-database-ofelection-reform-legislation.aspx, accessed March 26, 2014).

Neely, Francis, and Corey Cook. 2008. "Whose Votes Count? Undervotes, Overvotes, and Ranking in San Francisco’s Instant-Runoff Elections.” American Politics Research 36:530-554.

News Service of Florida. 2013. "Pinellas County Supervisor, Detzner Resolve Dispute.” Florida Courier, December 5 (accessed December 6, 2013).

Ohio Association of Election Officials. 2013a. "Report and Recommendations for Absentee Voting Reform,” November 13 (http://www.oaeo.us/report-and-recommendations-for-absenteevoting-reform/, accessed March 28, 2014). 
Ohio Association of Election Officials. 2013b. "Organization,” (http://www.oaeo.us/organization/, accessed March 28, 2014).

Pelzer, Jeremy. 2014. "Husted Sets Statewide Early-Voting Hours for General Election; Sundays not Included.” Cleveland Plain Dealer, February 25

(http://www.cleveland.com/open/index.ssf/2014/02/husted_sets_statewide_early-vo.html, accessed March 28, 2014).

Presidential Commission on Election Administration. 2014. The American Voting Experience: Report and Recommendations of the Presidential Commission on Election Administration. January 2014 (https://www.supportthevoter.gov/files/2014/01/Amer-Voting-Exper-final-draft01-09-14-508.pdf).

Robertson, Gary. 2014. “N.C. Counties Reduce Early Voting Hours for Primary.” The VirginianPilot, February 27 (http://hamptonroads.com/2014/02/nc-counties-reduce-early-voting-hoursprimary, accessed March 28, 2014).

Rodden, Jonathan. 2010. “The Geographic Distribution of Political Preferences.” Annual Review of Political Science 13:321-340.

Stein, Jason, and Don Walker. 2014. "Scott Walker Signs Early Voting Bill; Partial Veto Extends Voting Hours.” Milwaukee Journal Sentinel, March 27 (http://www.jsonline.com/news/statepolitics/scott-walker-signs-asbestos-lawsuit-billb99234687z1-252672541.html, accessed March 28, 2014).

Stein, Robert M., and Greg Vonnahme. 2008. “Engaging the Unengaged Voter: Vote Centers and Voter Turnout.” Journal of Politics 70:487-497.

Stewart, Charles, III. 2012. 2012 Survey of the Performance of American Elections. Presentation at The Pew Charitable Trust's Voting in America 2012 conference, December 10 (http://www.pewstates.org/uploadedFiles/PCS_Assets/2012/CharlesStewart-Day\%201.pptx).

Stewart, Charles. 2008. "2008 Survey of the Performance of American Elections", http://hdl.handle.net/1902.1/20580 UNF:5:K3Z+PFc/D3CggfRUHIytuw== V1 [Version]

Stuart, Guy. 2004. "Databases, Felons, and Voting: Bias and Partisanship of the Florida Felons List in the 2000 Elections.” Political Science Quarterly 119:453-475.

Walsh, Katherine Cramer. 2012. "Putting Inequality in its Place: Rural Consciousness and the Power of Perspective.” American Political Science Review 106:517-532. 
Figure 1

Percent of Jurisdictions and Ballots Cast in 2012 Election by Jurisdiction Size

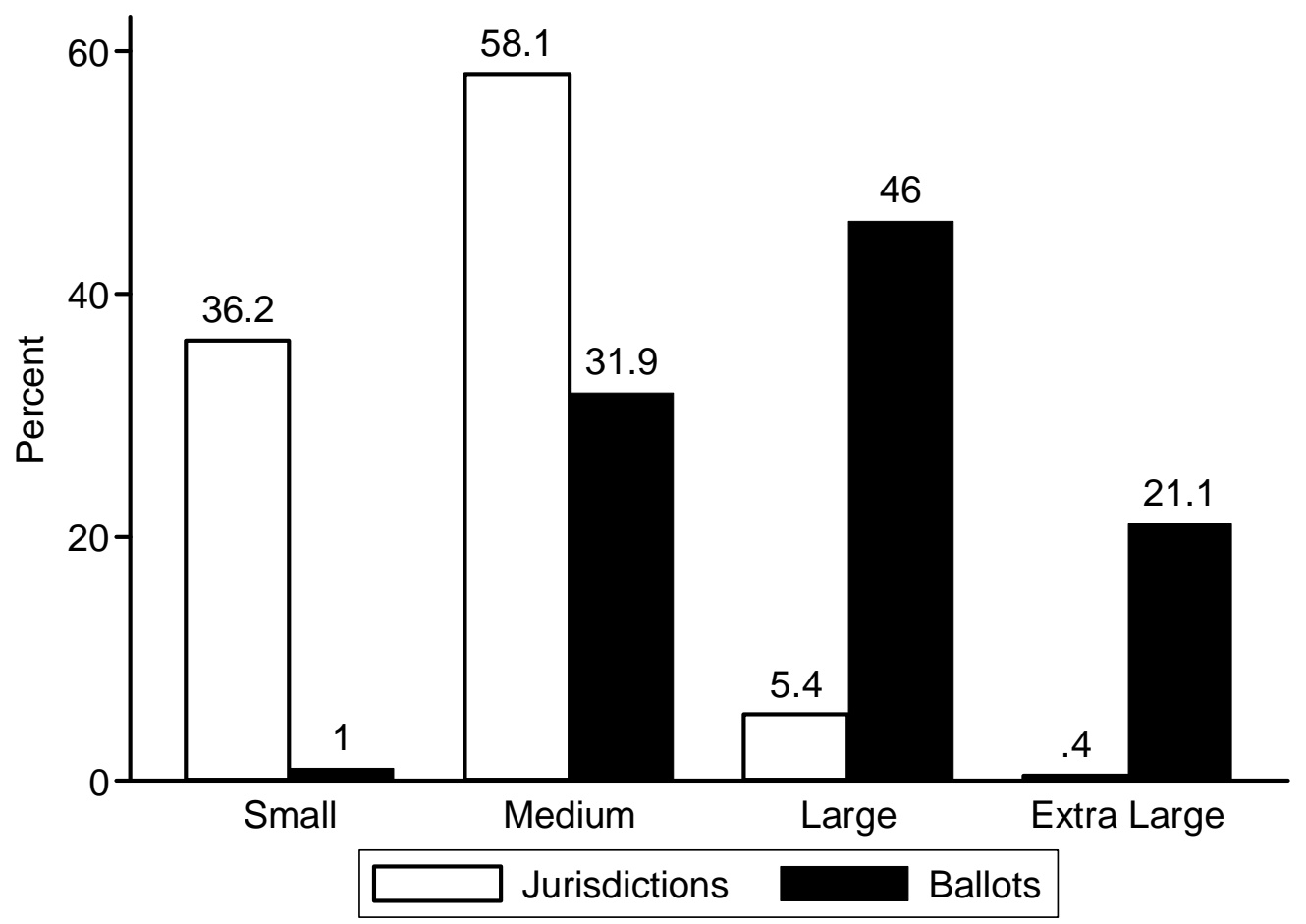


Figure 2

Change in Voter Turnout from 2004 to 2012 by Jurisdiction Size

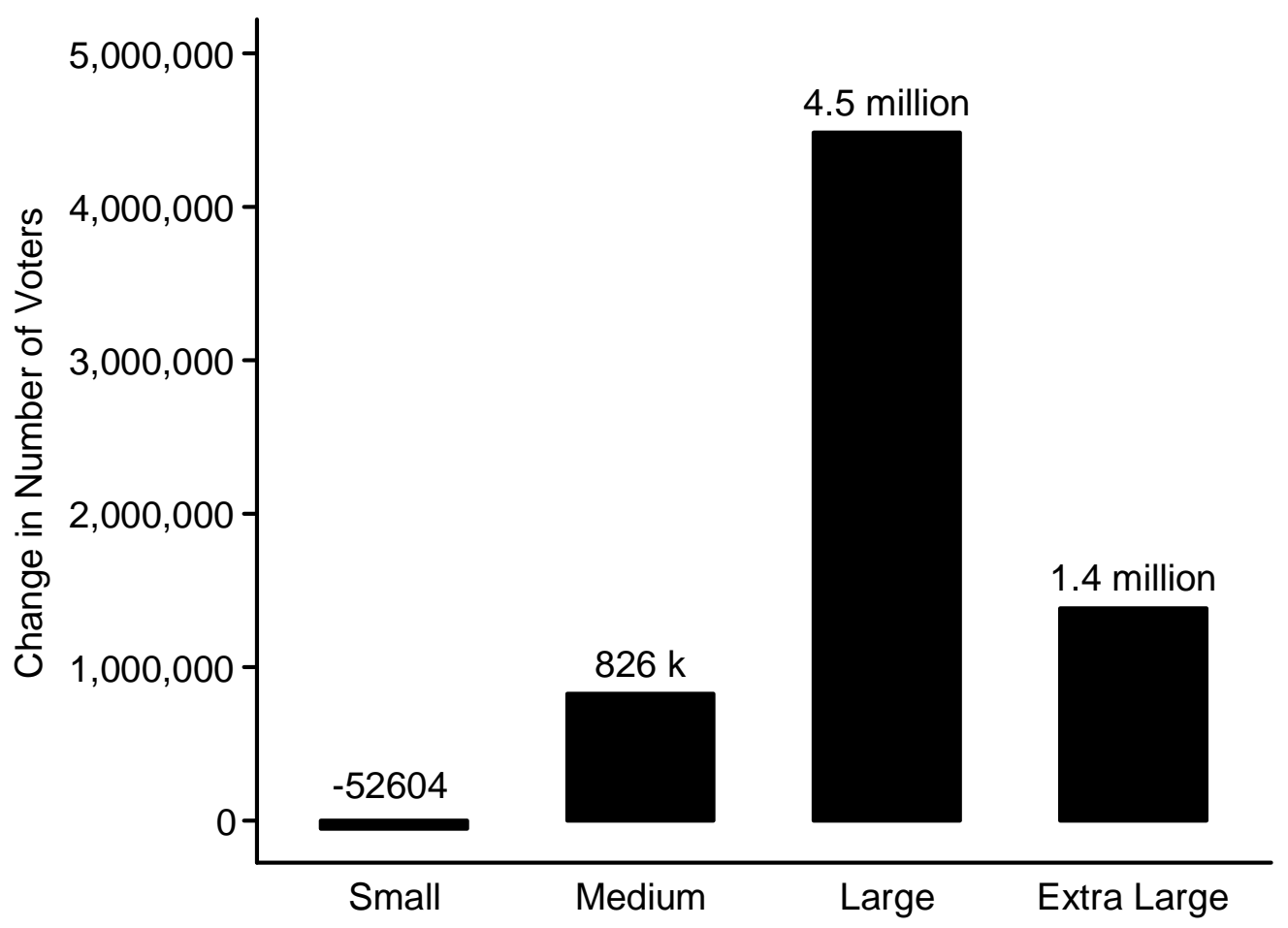


Figure 3

Percent of Ballots Cast by Jurisdiction Size in 2012 Presidential Election

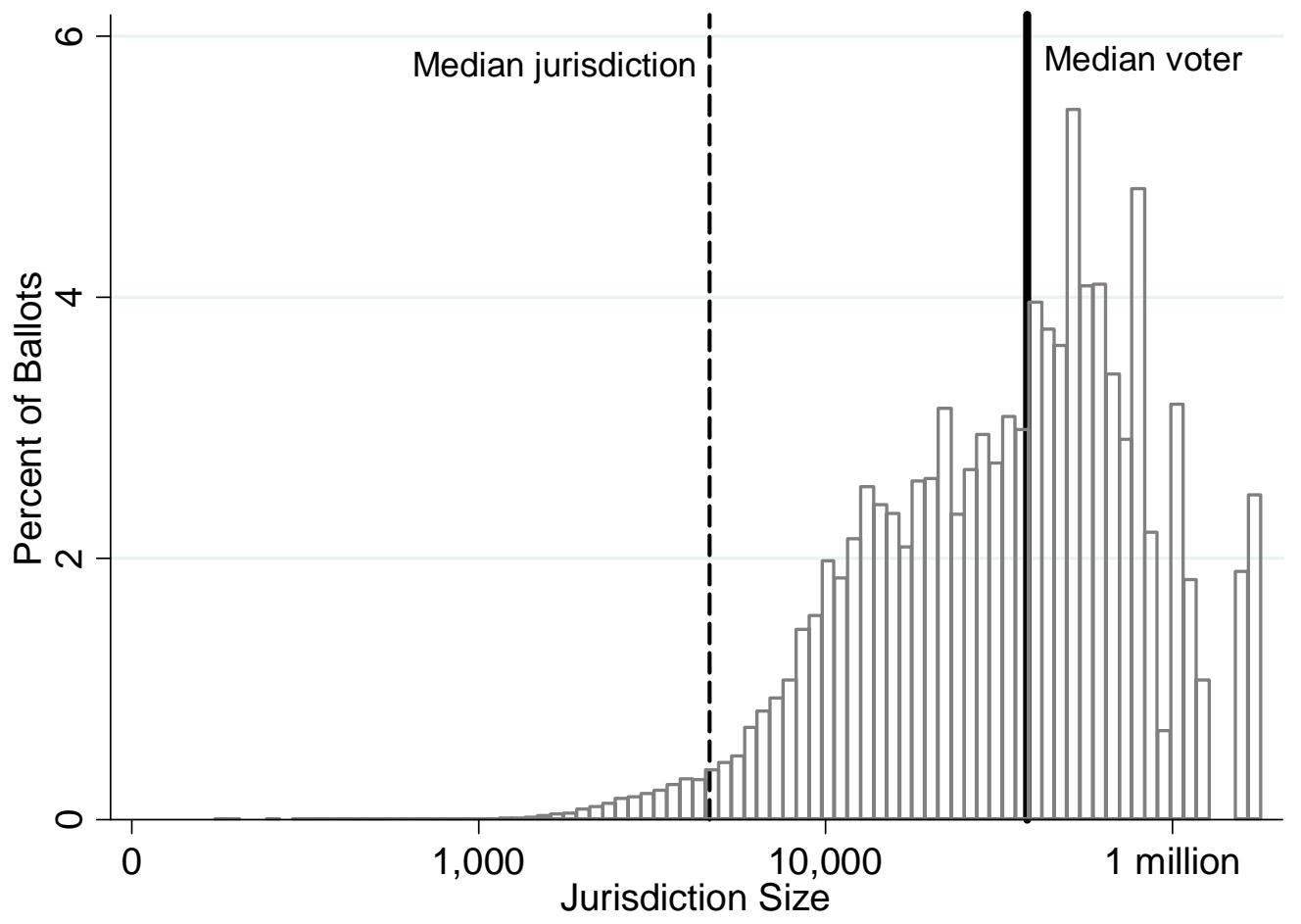

The horizontal axis is on a logarithmic scale, which reduces the skew. The dashed line indicates the median jurisdiction by size (roughly 2,100 voters).

The solid vertical line indicates the median voter (a jurisdiction of 144,000 voters). 
Figure 4

Obama's Share of Two-Party Presidential Vote in 2012 by Jurisdiction Size

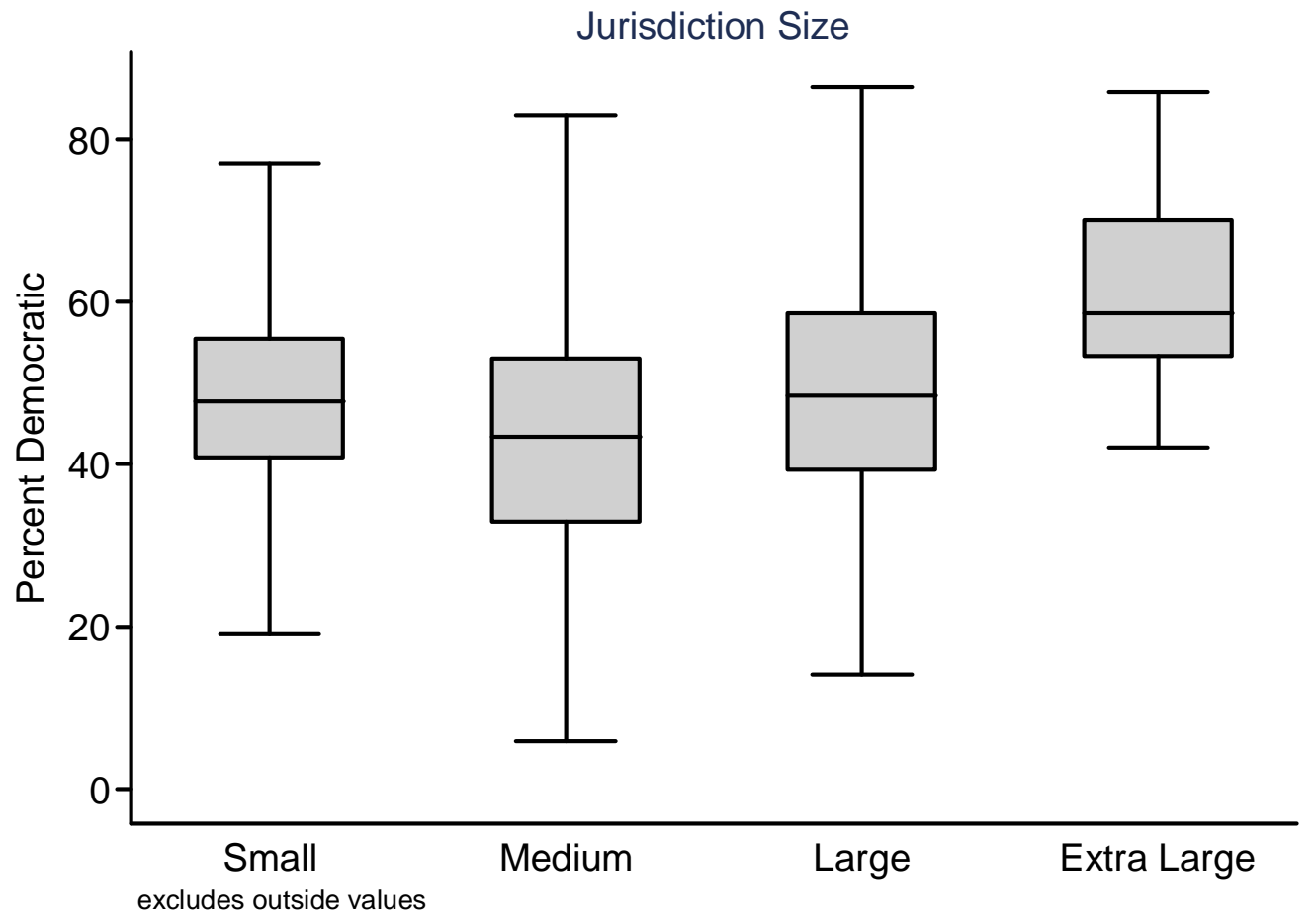


Table 1

Public Preferences for Expanded Voting Options by Size of Local Jurisdiction 2008 General Election

\begin{tabular}{|c|c|c|c|c|c|}
\hline \multirow[b]{2}{*}{ \% Support/\% Oppose } & \multicolumn{5}{|c|}{ Jurisdiction Size (number of voters in 2008) } \\
\hline & $\begin{array}{c}\text { Less than } \\
10,000\end{array}$ & $\begin{array}{c}\text { Between } \\
10,000 \text { and } \\
50,000 \\
\end{array}$ & $\begin{array}{c}\text { Between } \\
50,000 \\
\text { and } \\
100,000\end{array}$ & $\begin{array}{c}\text { Between } \\
100,000 \\
\text { and } \\
500,000\end{array}$ & $\begin{array}{c}\text { More than } \\
500,000\end{array}$ \\
\hline $\begin{array}{l}\text { Make Election Day a } \\
\text { national holiday }\end{array}$ & $50 / 50$ & $54 / 46$ & $58 / 42$ & $59 / 40$ & $58 / 41$ \\
\hline $\begin{array}{l}\text { Move Election Day to a } \\
\text { weekend }\end{array}$ & $38 / 62$ & $39 / 61$ & $42 / 58$ & $44 / 56$ & $45 / 54$ \\
\hline
\end{tabular}

Figures in the table indicate the percent of supporting and percent opposing each reform listed in the left-hand column.

Source: 2008 Survey of the Performance of American Elections 
Table 2

Hypothesized Interaction between Partisanship and Jurisdiction Size on Election Policy

\begin{tabular}{|l|l|c|c|}
\hline & \multicolumn{2}{|c|}{ Jurisdiction Size } \\
\hline & & Large/Urban & Small/Rural \\
\hline \multirow{2}{*}{$\begin{array}{c}\text { Partisanship of } \\
\text { Local Official }\end{array}$} & Republican & Support Innovation & Oppose Innovation \\
\cline { 2 - 4 } & Democrat & Support Innovation & $?$ \\
\hline
\end{tabular}

